\title{
Antioxidant Responses to Water Regimes by Sugarcane Varieties
}

\author{
S. Sree Ganesh ${ }^{1 *}$, Ajay V. Narwade ${ }^{1}$, S.C. Mali ${ }^{2}$, T.M. Neethu ${ }^{3}$, \\ Vivek N. Zinzala ${ }^{1}$ and Akshay N. Kudache ${ }^{1}$ \\ ${ }^{1}$ Department of Genetics and Plant Breeding, Navsari Agricultural Universtiy, \\ Navsari, Gujarat 396450, India \\ ${ }^{2}$ Main Sugarcane Research Station, Navsari Agricultural Universtiy, Navsari, \\ Gujarat 396450, India \\ ${ }^{3}$ Department of Soil Science and Agricultural Chemistry, NAU, Navsari, Gujarat 396450, India \\ *Corresponding author
}

\section{A B S T R A C T}

Sugarcane is most important cash crop of India and provides raw material for the second largest agro-based industry. In climate change scenario, water stress is the major factor that

\section{Keywords}

Sugarcane, Water regimes, Proline,

Glycine betaine,

Peroxidase,

Catalase.

Article Info

Accepted:

28 October 2017

Available Online:

10 December 2017 can limit the potential yield of sugarcane and exposure to water stress results in oxidative damage due to generation of reactive oxygen species. A field experiment was conducted to evaluate antioxidant responses of sugarcane varieties to water regimes during different growth phases. Four water regime treatments were applied i. e. at Establishment stage $\left(\mathrm{S}_{1}\right)$, Tillering stage $\left(S_{2}\right)$, Grand growth stage $\left(S_{3}\right)$ and Control $\left(S_{4}\right)$. Four sugarcane varieties were studied under this water regimes viz. CoN 04131, Co 86032, CoN 07072 and CoN 03131. The antioxidant like proline, glycine betaine, catalase and peroxidase were analysed. Under water stress conditions on different stages of sugarcane crop, it was observed that proline, glycine beatine, catalase and proxidase contents were increased under water stress conditions. The result indicates that variety $\mathrm{CoN} 04131$ showed the tolerant activity under stress conditions and proline, glycine betaine, catalase and peroxidase may be good biochemical markers for identification of drought tolerance in sugarcane.

\section{Introduction}

Sugarcane (Saccharum officinarum L.) is an important crop for sugar and bioenergy worldwide. Sugarcane is a major industrial crop cultivated in tropical and sub-tropical regions to produce sugar and the reduction in area under sugarcane cultivation and its yield mainly due to drought in almost the whole of tropical and sub-tropical regions (InmanBamber, 2005). Water deficit causes significant morphological and physiological and biochemical changes in plants (Creelman et al., 1990), severe deficit may lead to plant death (Cheng et al., 1993). On a cellular level, water deficit occurs when transpiration rates exceed water absorption, being the result of different types of stress and potentially leading to changes in concentration of solutes, cell volume and shape of membrane, changes in water potential gradients, loss of cell turgor, compromising of membrane integrity, protein denaturation, total loss of free water leading to dryness and dehydration (Bray, 
2000). Among the biochemical parameters like proline, glycine betaine, calatlase, proxidase are work as osmo protectants to rescues cell form death.

It is important to study the biochemical changes which are occurring during water stress conditions. The aim of present work was to study the antioxidant responses of sugarcane varieties at different growth phases under water regimes.

\section{Materials and Methods}

\section{Planting materials and treatments}

The experiment was conducted during 201415 and 2015-16 in split plot design with three replications at main sugarcane research station, Navsari Agricultural University, Navsari, Gujarat, India. Four water regime treatments were applied i. e. $\mathrm{S}_{1}: 30$ DAP Stress (30-90 days) (Establishment and early tillering stage), $\mathrm{S}_{2}$ : 60 DAP Stress (60-120 days) (Tillering stage), $S_{3}: 120$ DAP Stress (120-180 days) (Grand growth stage) and $\mathrm{S}_{4}$ : Irrigation as per recommendation (Control) as main plot treatment. During these periods water was not given. Four varieties viz. CoN 04131, Co 86032, CoN 07072 and CoN 03131were studied as sub plot treatment under these water regimes. Other recommended agronomical practices in vogue were followed for reaping good crop.

\section{Estimation of proline}

Free proline content was estimated by following the method of Bates et al., (1973). A known weight $(0.5 \mathrm{~g})$ of fresh leaf sample was macerated in a mortar using $10 \mathrm{ml}$ of 3 percent sulpha salicylic acid. The extract was filtered and $2.0 \mathrm{ml}$ of the filtrate was used for proline estimation. To this $2.0 \mathrm{ml}$ of filtrate, $2.0 \mathrm{ml}$ of acid ninhydrin reagent $(2.5 \mathrm{~g}$ of ninhydrin dissolved in $40 \mathrm{ml}$ of $6.0 \mathrm{M}$ orthophosphoric acid and $60 \mathrm{ml}$ of glacial acetic acid), $2.0 \mathrm{ml}$ of glacial acetic acid were added and placed in boiling water bath for one hour. Following this, test tubes containing the samples were transferred to an ice bath for cooling. The contents of each test tube were transferred to a separate funnel and $6.0 \mathrm{ml}$ of toluene was added, shaken thoroughly and allowed for few minutes for separation of two layers. The lower layer was discarded and the upper toluene layer containing the colour complex was taken into a test tube. The optical density was read at $520 \mathrm{~nm}$ using spectrophotometer (Model No: UV-1800, Shimadzu, UV spectrophotometer) and the proline content was calculated as on freshweight-basis as follows:

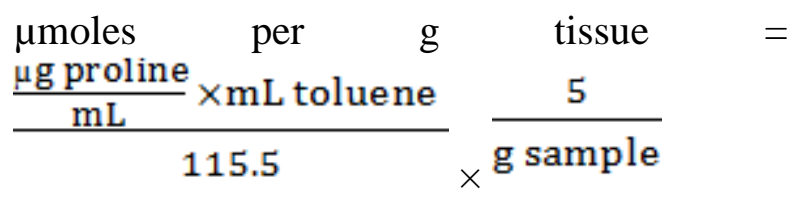

Where, 115.5 is the molecular weight of proline.

\section{Estimation of glycine betaine}

Estimation of glycine betaine was done by following the method of Grieve and Grattam, (1983). Leaf tissues (2.0g) were finelyground using liquid nitrogen in mortar-pestle. A finely ground plant sample $0.5 \mathrm{~g}$ of each genotype was mechanically shaken with 20 $\mathrm{ml}$ of deionized $\mathrm{H}_{2} \mathrm{O}$ for 24 hours at $250^{\circ} \mathrm{C}$. The samples were then filtered.

The extracts were diluted 1:1 with $2 \mathrm{~N} \mathrm{H}_{2} \mathrm{SO}_{4}$. Aliquots $(50 \mathrm{ml})$ were measured into $2.0 \mathrm{ml}$ Eppendrof tubes and cooled in ice-water for 1 hr. Cold KI- I2 reagent $(0.20 \mathrm{ml})$ was added to each tube and reactants gently stirred on a vortex mixer. The tubes were stored at $0-4^{\circ} \mathrm{C}$ for $16 \mathrm{hrs}$ and then centrifuged at $10000 \mathrm{rpm}$ for 15 mins at ${ }^{\circ} \mathrm{C}$. The supernatant were carefully aspirated. The per-iodide crystals 
were dissolved in $9.0 \mathrm{ml}$ of 1, 2dichloroethane. Vigorous vortex mixing was frequently required to effect complete solubilisation in the developing solvent. After 2-2.5 hrs, the absorbance was measured at $365 \mathrm{~nm}$ on a Spectrophotometer (UV-1800).

Reference standard of GB (50-200 microgram $/ \mathrm{ml}$ ) were prepared in $1 \mathrm{~N}_{2} \mathrm{SO}_{4}$. Standard curve were prepared and the GB content of sample calculated.

Glycine betaine $=$ Sample O. D. $\times$ Graph factor $\times$ Dilution factor

\section{Estimation of catalase}

CAT activity was measured by following the decomposition of hydrogen peroxide as described by Cakmak and Marschner (1992) with some modifications. The activity was measured in a reaction mixture $(1 \mathrm{ml})$ containing $50 \mathrm{mM}$ phosphate buffer $(\mathrm{pH}$ 7.0) and $15 \mathrm{mM} \mathrm{H}_{2} \mathrm{O}_{2}$. The reaction was initiated by adding $50 \mathrm{ml}$ enzyme extract and the activity was determined by monitoring decrease in absorbance at $240 \mathrm{~nm}$ for $2 \mathrm{~min}$ at intervals of $15 \mathrm{~s}$. The slope of the rate assay (DA) was used to determine the enzyme activity, which was expressed as $\mathrm{mK}$ at $\mathrm{mg}^{-1}$ protein.

\section{Estimation of peroxidase}

APX activity was determined according to Nakano and Asada (1981). The reaction mixture (a total volume of $2 \mathrm{~mL}$ ) consisted of $50 \mathrm{mM}$ (pH 7.0) sodium phosphate buffer, 0.1 mM EDTA, $0.25 \mathrm{mM}$ ascorbate, $1 \mathrm{mM} \mathrm{H}_{2} \mathrm{O}_{2}$ (hydrogen peroxide), and $100 \mathrm{ml}$ enzyme extract.

The $\mathrm{H}_{2} \mathrm{O}_{2}$-dependent oxidation of ascorbate was followed by a decrease in the absorbance at $290 \mathrm{~nm}$. APX activity was measured in

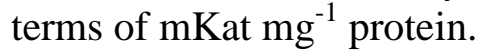

\section{Results and Discussion}

\section{Proline $\left(\mu \mathrm{ugg}^{-1} \mathrm{FW}\right)$}

The data in respect to the effect of water regimes $(\mathrm{S})$, variety $(\mathrm{V})$ and their interaction $(\mathrm{S} x \mathrm{~V})$ on proline content of sugarcane were recorded at 90, 120 and 180 DAP during 2014-15, 2015-16 and pooled data were depicted in Table 1.

Among the water regimes treatments, the establishment stage $\left(\mathrm{S}_{1}\right)$ at $90 \mathrm{DAS}$, Tillering stage (S2) at 120 DAS and Grand growth stage (S3) at 180 DAS respectively showed the highest mean proline content (16.78, 21.76 and 28.96) and the lowest were recorded with $\mathrm{S}_{4}$ (Control) (13.65, 19.43 and 25.31) in pooled of both years. The highest mean significant proline content $(16.72,21.83$ and 28.65) were recorded in $\mathrm{V}_{1}(\mathrm{CoN} 04131)$ and lowest (20.02 and 14.06) were recorded in $\mathrm{V}_{4}(\mathrm{CoN}$ 03131) at 90 and 120 DAS and at 180 DAS (26.10) was recorded in V3 (CoN 07072) among varieties (V) in pooled of both years.

The interaction effects $(\mathrm{S} \times \mathrm{V})$ of proline content at 90 DAP during pooled of 2014-15 and 2015-16 were recorded significantly. The date revealed that the highest mean proline content (18.95) was recorded significantly in the treatment combination $\mathrm{S}_{1} \mathrm{~V}_{1}$ (Establishment and $\mathrm{CoN}$ 04131) during pooled of 2014-15 and 2015-16. The lowest proline content (12.64) was found in $\mathrm{S}_{4} \mathrm{~V}_{4}$ (Control and CoN 03131). At 120 and 180 DAS the interaction effect was found nonsignificant.

\section{Glycine betaine $\left(\mu \mathrm{gg}^{-1} \mathrm{FW}\right)$}

The data regarding to glycine betaine content of sugarcane were significantly influenced by the water regimes $(\mathrm{S})$, variety $(\mathrm{V})$ and their interaction $(\mathrm{S} \times \mathrm{V})$ were recorded at 90, 120 
and 180 DAP during 2014-15, 2015-16 and pooled data were presented in Table 2. The highest mean glycine betaine content of $173.35,270.36$ and 322.80 were recorded respectively with the water regimes treatment $\mathrm{S}_{1}$ (Establishment) at $90 \mathrm{DAS}$, Tillering stage (S2) at 120 DAS and Grand growth stage (S3) at $180 \mathrm{DAS}$. The lowest were recorded with $\mathrm{S}_{4}$ (Control) (159.77, 238.30 and 286.54). The variety V1 (CoN 04131) was showed the highest glycine beatien content respectively (171.60, 258.83 and 309.64) and lowest (162.74, 300.33 and 245.04) was recorded with CoN 03131. Among the interaction effects $(\mathrm{S} \times \mathrm{V})$ of glycine betaine at 180 DAP during pooled of 2014-15, 2015-16 was found significant. The date observed that the highest mean glycine betaine (328.72) was recorded significantly in the treatment combination $\mathrm{S}_{3} \mathrm{~V}_{1}$ (Grand growth and $\mathrm{CoN}$ 04131) followed by the treatment $\mathrm{S}_{3} \mathrm{~V}_{2}$ (Grand growth and Co 86032) (327.39) and the lowest (281.93) were recorded in the treatment combination $\mathrm{S}_{4} \mathrm{~V}_{3}$ (Control and $\mathrm{CoN}$ 07072) in pooled of both years.

\section{Catalase ( $\mathrm{mK}$ at $\left.\mathrm{mg}^{-1}\right)$}

The mean catalase activity at 90,120 and 180 DAP during 2014-15, 2015-16 were significantly affected by the water regimes $(\mathrm{S})$, Variety (V) and their interaction $(\mathrm{S} x \mathrm{~V})$ were depicted in Table 3.

Significantly highest mean catalase activity (1.24, 2.50 and 1.69) were recorded in S1 (Establishment) at 90 DAS, Tillering stage (S2) at 120 DAS and Grand growth stage (S3) at 180 and the lowest were recorded with $\mathrm{S}_{4}$ (Control) (0.81, 1.20 and 1.90) in pooled of both years. The highest mean significant catalase activity $(1.15,1.62$ and 2.40$)$ were recorded in $\mathrm{V}_{1}(\mathrm{CoN} 04131)$ and lowest (0.85, 1.32 and 1.92). The interaction effects ( $\mathrm{S} \times \mathrm{V})$ of catalase activity at 180 DAP during pooled of 2014-15 and 2015-16 were recorded significantly. The date revealed that the highest mean catalase activity (2.86) was recorded significantly in the treatment combination $\mathrm{S}_{3} \mathrm{~V}_{1}$ (Grand growth and $\mathrm{CoN}$ 04131) followed by the treatment $S_{3} V_{2}$ (Grand growth and Co 86032) (2.51) and the lowest (1.76) were recorded in the treatment combination $\mathrm{S}_{4} \mathrm{~V}_{3}$ (Control and CoN 07072).

\section{Peroxidase ( $\mathrm{mK}$ at $\left.\mathrm{mg}^{-1}\right)$}

The data in respect to the effect of water regimes (S), variety (V) and their interaction $(\mathrm{S} \times \mathrm{V})$ on peroxidase content of sugarcane were recorded at 90, 120 and 180 DAP during 2014-15 and 2015-16 and pooled data were depicted in Table 4.

The highest mean peroxidase content (10.04, 10.62 and 10.08) were significantly recorded in S1 (Establishment) at 90 DAS, Tillering stage (S2) at 120 DAS and Grand growth stage (S3) at 180 and the lowest were recorded with $\mathrm{S}_{4}$ (Control) (5.85, 6.35 and 6.87) among water regimes (S) in pooled of both years. The highest peroxidase content (9.26, 10.02 and 9.84) were recorded in $\mathrm{V}_{1}$ (CoN 04131) and lowest (5.86, 6.17 and 6.87) were recorded in $\mathrm{V}_{4}(\mathrm{CoN}$ 03131) among varieties (V) in pooled of both years. The interaction effects ( $\mathrm{S} \times \mathrm{V}$ ) of catalase activity at 120 DAP during 2014-15 and 2015-16 were recorded significantly. The data revealed the highest mean peroxidase content (10.86) in $\mathrm{S}_{2} \mathrm{~V}_{1}$ (Tillering stage and $\mathrm{CoN}$ 04131) and the lowest (3.15) were recorded in the treatment combination $\mathrm{S}_{4} \mathrm{~V}_{4}$ (Control and CoN 03131). In the present work, free proline content increased due to water stress in the leaves in all varieties of sugarcane. In present investigation, among water regimes control conditions (S4) showed the lowest value and stress conditions at 90 DAP (Establishment stage), 120 DAP (Tillering stage) and 180 DAP (Grand Growth stage) shows the highest proline content (Table 1). 
Table.1 Effect of water regimes on pooled data of proline $\left(\mu \mathrm{gg}^{-1} \mathrm{FW}\right)$ of sugarcane at 90,120 and 180 days during 2014-15 and 2015-16

\begin{tabular}{|c|c|c|c|c|c|c|c|c|c|c|c|c|c|c|c|c|c|}
\hline \multicolumn{6}{|c|}{90 DAS } & \multicolumn{6}{|c|}{120 DAS } & \multicolumn{6}{|c|}{180 DAS } \\
\hline & $V_{1}$ & $V_{2}$ & $\mathbf{V}_{\mathbf{3}}$ & $\mathbf{V}_{4}$ & Mean & & $V_{1}$ & $V_{2}$ & $V_{3}$ & $\mathrm{~V}_{4}$ & Mean & & $V_{1}$ & $V_{2}$ & $V_{3}$ & $\mathbf{V}_{4}$ & Mean \\
\hline $\mathbf{S}_{1}$ & 18.95 & 16.86 & 16.24 & 15.06 & 16.78 & S1 & 21.97 & 21.16 & 20.52 & 19.97 & 20.91 & $\mathbf{S}_{1}$ & 27.94 & 25.80 & 25.82 & 27.21 & 27.19 \\
\hline $\mathbf{S}_{2}$ & 16.31 & 15.30 & 14.32 & 14.98 & 15.23 & S2 & 23.17 & 21.61 & 21.54 & 20.72 & 21.76 & $\mathbf{S}_{2}$ & 29.67 & 28.73 & 26.60 & 28.22 & 27.30 \\
\hline $\mathbf{S}_{3}$ & 16.60 & 15.33 & 15.02 & 13.56 & 15.13 & S3 & 21.79 & 20.14 & 20.87 & 20.39 & 20.79 & $\mathbf{S}_{3}$ & 30.39 & 29.95 & 26.82 & 28.71 & 28.96 \\
\hline $\mathbf{S}_{4}$ & 15.00 & 13.93 & 13.02 & 12.64 & 13.65 & S4 & 20.37 & 19.14 & 19.17 & 19.02 & 19.43 & $\mathbf{S}_{4}$ & 26.59 & 26.51 & 25.14 & 27.01 & 25.31 \\
\hline Mean & 16.72 & 15.35 & 14.65 & 14.06 & & Mean & 21.83 & 20.51 & 20.52 & \multicolumn{2}{|l|}{20.02} & Mean & 28.65 & 27.75 & 26.10 & 27.79 & \\
\hline & \multirow{2}{*}{\multicolumn{2}{|c|}{$\mathbf{S}$}} & & \multirow{2}{*}{\multicolumn{2}{|c|}{ S X V }} & & \multirow{2}{*}{\multicolumn{2}{|c|}{$\mathbf{S}$}} & & \multirow{2}{*}{\multicolumn{2}{|c|}{ S X V }} & & \multirow{2}{*}{\multicolumn{2}{|c|}{$\mathbf{S}$}} & \multirow{2}{*}{\multicolumn{2}{|c|}{$\mathbf{V}$}} & \\
\hline & & & V & & & & & & V & & & & & & & & $\mathbf{S X V}$ \\
\hline $\begin{array}{c}\text { CD } \\
(P=0.05 \%)\end{array}$ & \multicolumn{2}{|c|}{0.4537} & 0.2862 & \multicolumn{2}{|c|}{0.5724} & $\begin{array}{c}\text { CD } \\
(P=0.05 \%)\end{array}$ & \multicolumn{2}{|c|}{0.7362} & 0.4342 & \multicolumn{2}{|r|}{ NS } & $\begin{array}{c}\text { CD } \\
(P=0.05 \%)\end{array}$ & \multicolumn{2}{|c|}{1.1431} & \multicolumn{2}{|c|}{0.6938} & NS \\
\hline S.Em + & 0.147 & & 0.1007 & & 2013 & S.Em \pm & 0.23 & & 0.1527 & & .3054 & S.Em + & 0.37 & & 0.24 & & 0.4880 \\
\hline C.V.\% & 4.128 & & & & 8221 & C.V.\% & 5.05 & & & & .2307 & C.V.\% & 7.20 & & & & 4.7404 \\
\hline
\end{tabular}

Table.2 Effect of water regimes on pooled data of glycine betaine content $\left(\mu \mathrm{gg}^{-1} \mathrm{FW}\right)$ of sugarcane at 90,120 and 180 days during 2014-15 and 2015-16

\begin{tabular}{|c|c|c|c|c|c|c|c|c|c|c|c|c|c|c|c|c|c|}
\hline \multicolumn{6}{|c|}{90 DAS } & \multicolumn{6}{|c|}{120 DAS } & \multicolumn{6}{|c|}{180 DAS } \\
\hline & $V_{1}$ & $\mathbf{V}_{2}$ & $\mathbf{V}_{3}$ & \multirow{2}{*}{$\frac{\mathbf{V}_{4}}{168.97}$} & Mean & & $V_{1}$ & $\mathbf{V}_{2}$ & $\mathbf{V}_{\mathbf{3}}$ & \multirow{2}{*}{$\frac{\mathbf{V}_{\mathbf{4}}}{246.29}$} & Mean & & $V_{1}$ & $\mathbf{V}_{2}$ & $\mathbf{V}_{\mathbf{3}}$ & $V_{4}$ & Mean \\
\hline$S_{1}$ & 177.18 & 174.78 & 172.48 & & 173.35 & S1 & 254.90 & 251.03 & 250.05 & & 250.56 & $\mathbf{S}_{1}$ & 310.63 & 301.09 & 296.56 & 303.76 & 303.01 \\
\hline $\mathbf{S}_{2}$ & 172.10 & \multirow[t]{2}{*}{168.55} & 164.87 & $\begin{array}{l}168.97 \\
163.35\end{array}$ & 167.22 & S2 & 277.07 & 273.04 & 265.32 & 266.00 & 270.36 & $\mathbf{S}_{2}$ & 305.93 & 310.63 & 282.62 & 295.51 & 298.67 \\
\hline $\mathbf{S}_{3}$ & 173.88 & & 165.85 & 162.60 & 167.70 & S3 & 258.85 & 253.32 & 241.87 & 232.88 & 246.73 & $\mathbf{S}_{3}$ & 328.72 & 327.39 & 314.90 & 319.19 & 322.80 \\
\hline $\mathbf{S}_{4}$ & 163.22 & $\begin{array}{l}168.47 \\
161.02\end{array}$ & 158.78 & 156.05 & 159.77 & S4 & 244.48 & 238.44 & 235.30 & 234.97 & 238.30 & $\mathbf{S}_{4}$ & 293.29 & 288.06 & 281.93 & 282.88 & 286.54 \\
\hline Mean & 171.60 & 168.20 & 165.50 & 162.74 & & Mean & 258.83 & 253.96 & 248.13 & 245.04 & & Mean & 309.64 & 305.04 & 294.00 & 300.33 & \\
\hline & \multicolumn{2}{|l|}{$\mathbf{S}$} & \multicolumn{3}{|c|}{ S X V } & & \multicolumn{2}{|l|}{$\mathbf{S}$} & \multicolumn{3}{|r|}{ SX V } & & \multicolumn{2}{|c|}{$\mathbf{S}$} & \multicolumn{2}{|l|}{ V } & SX V \\
\hline $\begin{array}{c}\mathrm{CD} \\
(\mathrm{P}=\mathbf{0 . 0 5} \%)\end{array}$ & \multicolumn{2}{|c|}{4.2777} & \multicolumn{2}{|l|}{2.5677} & NS & $\begin{array}{c}\mathrm{CD} \\
(\mathrm{P}=\mathbf{0 . 0 5 \%})\end{array}$ & \multicolumn{2}{|c|}{6.7566} & 4.6741 & \multicolumn{2}{|r|}{ NS } & $\begin{array}{c}\mathrm{CD} \\
(\mathrm{P}=0.05 \%)\end{array}$ & \multicolumn{2}{|c|}{7.6862} & \multicolumn{2}{|c|}{2.7936} & 5.5871 \\
\hline S.Em + & \multirow{2}{*}{\multicolumn{2}{|c|}{\begin{tabular}{|l|}
1.3883 \\
4.0723
\end{tabular}}} & \multirow{2}{*}{\multicolumn{3}{|c|}{\begin{tabular}{|l|}
1.8061 \\
26489
\end{tabular}}} & S.Em \pm & \multicolumn{2}{|c|}{2.1928} & 1.6438 & & 3.2876 & S.Em + & 2.4 & & 0.982 & & 1.9649 \\
\hline C.V.\% & & & & & & C.V.\% & 4.27 & & & & 3.2021 & C.V.\% & 4.0 & 364 & & & 1.5897 \\
\hline
\end{tabular}


Table.3 Effect of water regimes on pooled data of catalase ( $\mathrm{mK}$ at $\mathrm{mg}^{-1}$ ) of sugarcane at 90,120 and 180 days during 2014-15 and 2015-16

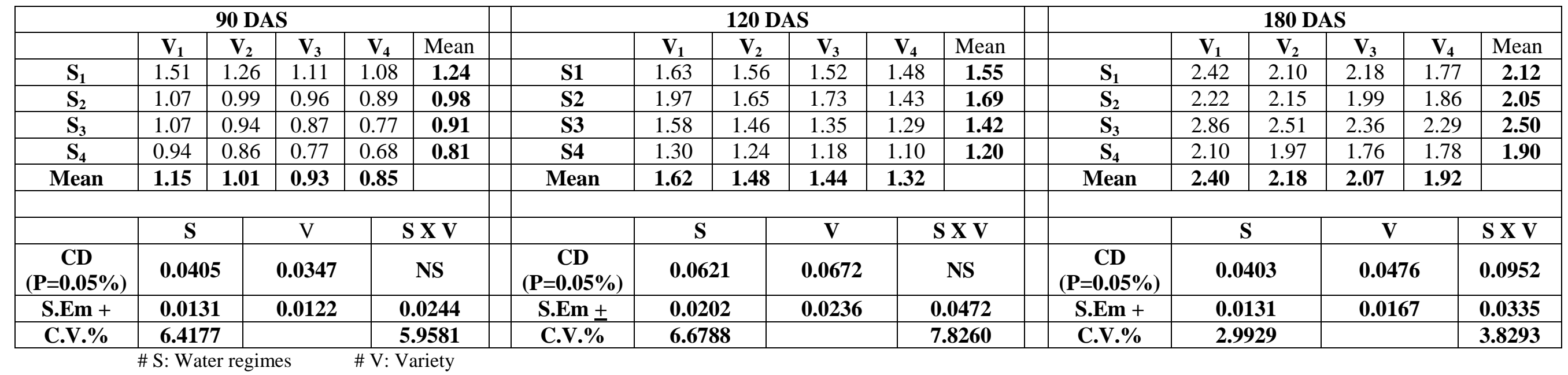

Table.4 Effect of water regimes on pooled data of peroxidase ( $\mathrm{mK}_{\text {at }} \mathrm{mg}^{-1}$ ) of sugarcane at 90, 120 and 180 days during 2014-15 and 2015-16

\begin{tabular}{|c|c|c|c|c|c|c|c|c|c|c|c|c|c|c|c|c|c|}
\hline \multicolumn{6}{|c|}{90 DAS } & \multicolumn{6}{|c|}{120 DAS } & \multicolumn{6}{|c|}{180 DAS } \\
\hline & $V_{1}$ & $\mathbf{V}_{2}$ & $\mathbf{V}_{3}$ & $\mathbf{V}_{4}$ & Mean & & $V_{1}$ & $\mathbf{V}_{2}$ & $\mathbf{V}_{3}$ & $\mathbf{V}_{4}$ & Mean & & $V_{1}$ & $V_{2}$ & $\mathbf{V}_{\mathbf{3}}$ & $\mathbf{V}_{4}$ & Mean \\
\hline$S_{1}$ & 10.05 & 9.90 & 10.22 & 10.00 & 10.04 & S1 & 9.60 & 9.81 & 10.83 & 9.60 & 9.96 & $S_{1}$ & 9.67 & 9.35 & 9.46 & 9.07 & 9.39 \\
\hline $\mathbf{S}_{2}$ & 9.27 & 8.62 & 8.73 & 8.67 & 8.82 & S2 & 10.86 & 10.17 & 11.19 & 10.28 & 10.62 & $\mathbf{S}_{2}$ & 11.46 & 10.94 & 10.07 & 5.25 & 9.43 \\
\hline $\mathbf{S}_{3}$ & 9.40 & 9.12 & 9.65 & 2.48 & 7.66 & $\mathbf{S 3}$ & 10.18 & 9.44 & 9.33 & 3.50 & 8.11 & $\mathbf{S}_{3}$ & 10.43 & 9.72 & 10.03 & 9.23 & 10.08 \\
\hline $\mathbf{S}_{4}$ & 8.31 & 8.24 & 4.52 & 2.31 & 5.85 & S4 & 9.42 & 8.40 & 4.52 & 3.15 & 6.87 & $\mathbf{S}_{4}$ & 7.79 & 8.16 & 5.54 & 3.93 & 6.35 \\
\hline Mean & 9.26 & 8.97 & 8.28 & 5.86 & & Mean & 10.02 & 9.46 & 8.97 & 6.17 & & Mean & 9.84 & 9.54 & 8.77 & $\begin{array}{l}5.95 \\
6.87 \\
\end{array}$ & \\
\hline & \multicolumn{2}{|l|}{$\mathbf{S}$} & $\mathrm{V}$ & \multicolumn{2}{|c|}{ S X V } & & \multicolumn{2}{|c|}{$\mathbf{S}$} & V & \multicolumn{2}{|c|}{ S X V } & & \multicolumn{2}{|c|}{$\mathbf{S}$} & \multicolumn{2}{|l|}{$\mathbf{V}$} & $\mathbf{S X V}$ \\
\hline $\begin{array}{c}\text { CD } \\
(P=0.05 \%)\end{array}$ & \multicolumn{2}{|c|}{0.1896} & 0.2661 & \multicolumn{2}{|r|}{ NS } & $\begin{array}{c}C D \\
(P=0.05 \%)\end{array}$ & \multicolumn{2}{|c|}{0.3556} & 0.2544 & \multicolumn{2}{|c|}{0.5087} & $\begin{array}{c}C D \\
(P=0.05 \%)\end{array}$ & \multicolumn{2}{|c|}{0.3054} & \multicolumn{2}{|c|}{0.4595} & NS \\
\hline S.Em + & \multirow{2}{*}{\multicolumn{2}{|c|}{$\begin{array}{l}0.0615 \\
3170\end{array}$}} & 0.0936 & \multirow{2}{*}{\multicolumn{2}{|c|}{$\begin{array}{l}0.1872 \\
50465\end{array}$}} & S.Em \pm & \multicolumn{2}{|c|}{0.1154} & 0.0895 & \multirow{2}{*}{\multicolumn{2}{|c|}{$\begin{array}{l}0.1789 \\
45117\end{array}$}} & S.Em + & \multicolumn{2}{|c|}{0.0991} & \multicolumn{2}{|c|}{0.1616} & 0.3232 \\
\hline C.V.\% & & & & 5.0465 & & C.V.\% & \multicolumn{2}{|c|}{5.8211} & & & & C.V.\% & \multicolumn{2}{|c|}{5.0853} & & & 4.2928 \\
\hline
\end{tabular}


Such a situation was observed in other sugarcane varieties also (Queiroz et al., 2008). According to Ashraf and Foolad (2007), the accumulation of proline is the first response of plants exposed to water stress in order to reduce injuries to the cells. The important role of proline to drought tolerance assisting in osmotic adjustment stabilizing the membrane and eliminating oxygen radicals, and preventing damage to cell structures caused by environmental stresses is a matter of study (Silva et al., 2013).

The data presented in Table 2 indicated that glycine betaine content significantly differed among different varieties in different water regimes. Susceptible variety (CoN 03131) shows the minimum content of glycine betaine than tolerance variety ( $\mathrm{CoN}$ 04131). The results are homologous to the findings of Abdul et al., 2007. Water stress has profound effects on the GB accumulation in sugarcane.

The accumulation of GB might serve as an intercellular osmoticum of GB and could be closely correlation with elevation of osmotic pressure. GB maintains the osmoticum, provided that the basal metabolism of the plant can sustain a high rate of synthesis of these compounds to facilitate osmotic adjustment for tolerance to drought.

The data depicted in Table 3 indicated that different water regimes are significantly affected the catalase activity. Among the water regimes at 90 DAP, the establishment stage $\left(\mathrm{S}_{1}\right)$ shows the maximum catalase activity, at 120 DAP, the tillering stage $\left(\mathrm{S}_{2}\right)$ showed the highest catalase activity and at 120 DAP the grand growth stage $\left(\mathrm{S}_{3}\right)$ shows the maximum catalase activity compared to control treatment $\left(\mathrm{S}_{4}\right)$ which showed lowest. An observation on varietal differences showed the CoN 04131 shows highest catalase activity and $\mathrm{CoN} 03131$ variety shows significantly lowest values.
The accumulation of osmoregulators in response to drought is an important mechanism for maintaining cell turgor, contributing to alleviate the reduction of the water potential. Previous studies have observed an increase in solutes in sugarcane and other species under water-deficient conditions (Ashraf and Foolad, 2007). The accumulation of those compounds in leaves and roots of the stressed plants was an important mechanism for osmoprotection and osmoregulation during drought conditions.

In the present work, peroxidase content increased due to water stress in the leaves in all varieties of sugarcane in all stages of crop. In present investigation, among water regimes control conditions (S4) showed the lowest peroxidase and stress conditions at 90 DAP (Establishment stage), 120 DAP (Tillering stage) and 180 DAP (Grand Growth stage) shows the highest peroxidise content (Table 6). Susceptible variety ( $\mathrm{CoN}$ 03131) shows the minimum content of peroxidise content than tolerance variety ( $\mathrm{CoN}$ 04131). The results are homologous to the findings of Merlin Christy et al., (2012) and Hemaprabha et al., (2013).

\section{References}

Abdul Jaleel, C., Sankar, B., Manivannan, P., Kishorekumar, A., Sridharan, R. and Panneerselvam, R. (2007). Calcium chloride effect on salinity induced oxidative stress, proline metabolism and indole alkaloid accumulation in Catharanthus roseus. Comptes Rendes Biologies, 330: 674-683.

Ashraf, M. and Foolad, M. R. (2007). Roles of glycine betaine and proline in improving plant abiotic stress resistance. Environmental and Experimental Botany, 59:206-216.

Bates, L. S., Wakdren, R. P. and Teare, J. D. (1973). Rapid determination of free 
proline for water use studies. Plant and Soil, 39: 205-208.

Bray, E.A., Bailey-Serres, J. and Weretilnyk, E. (2000). Responses to abiotic stresses. In: Buchanan, B.B., Gruissem, W., Jones, R.L. (ed.): Biochemistry and Molecular Biology of Plants. pp 11581203. American Society of Plant Physiologists, Rockville.

Cakmak, I., Marschner, H. (1992). Magnesium deficiency and high light intensity enhance activities of superoxide dismutase, ascorbate peroxidase and glutathione reductase in bean leaves. Plant Physiol, 98: 12221227.

Creelman, R. A., Mason, H. S., Bensen, R. J., Boyer, J. S. and Mullet, J. E. (1990). Water deficit and abscisic acid cause differential inhibition of shoot versus root growth in soybean seedlings. Plant Physiology. 92: 205-214.

Greive, C. M. and Grattan, S. R. (1983). Rapid assay for determination of watersoluble quaternary amino compounds. Plant Soil, 70: 303-307.

Hemaprabha, G., Swapna, S., Leena Lavanya, D., Sajitha, B. and Venkataramana, S. (2013). Evaluation of Drought Tolerance Potential of Elite Genotypes and Progenies of Sugarcane (Saccharum sp. hybrids). 15 (1):9-16.
Inman-Bamber, N. G., Bonnett, G. D., Smith, D. M. and Thorburn, P. J. (2005). Sugarcane physiology: Integrating from cell to crop to advance sugarcane production. Field Crops Res., 92:115117.

Merlin Christy, P., Dharani Preetha1, R.., Vasantha, S. and Divya, D. (2012). Biochemical and molecular analysis of sugarcane genotypes response to salinity and drought. International Journal of Applied Biology and Pharmaceutical Technology. 4(1):210218.

Nakano, Y. and Asada, K. (1981). Hydrogen Peroxide Is Scavenged by AscorbateSpecific Peroxidase in Spinach Chloroplasts. Plant and Cell Physiology, 22: 867-880.

Queiroz, R. J. B., Santos, D. M. M., Carlin, S. D., Marin, A., Banzatto, D. A. and Cazetta, J. O. (2008). Effects of osmoprotectors on sugarcane plants growing under different water deficit levels. Científica, 36:107-115.

Silva, E. C., Albuquerque, M. B., Azevedo Neto, A. D. and Silva Junior, C. D. (2013). Drought and its consequences to plants from individual to ecosystem. Responses of organisms to water stress. Croatia: In Tech., pp.17-47.

\section{How to cite this article:}

Sree Ganesh, S., Ajay V. Narwade, S.C. Mali, T.M. Neethu, Vivek N. Zinzala and Akshay N. Kudache. 2017. Antioxidant Responses to Water Regimes by Sugarcane Varieties. Int.J.Curr.Microbiol.App.Sci. 6(12): 4102-4109. doi: https://doi.org/10.20546/ijcmas.2017.612.471 